\title{
ETNOZOOLOGI SUKU DAYAK KANAYANT DI DESA TEMAHAR KECAMATAN JELIMPO KABAUPATEN LANDAK
}

\author{
(Etnozoology For Comsumption Of Dayak Kanayant In Temahar. Village Jelimpo Distric \\ Landak Regency)
}

\author{
Benediktus Almey GP, M. Sofwan Anwari, Ir. Ahmad Yani \\ Fakultas Kehutanan Universitas Tanjungpura, Jalan Imam Bonjol Pontianak, 78124 \\ E-mail: bayuagp94@yahoo.com
}

\begin{abstract}
The utilization of protected animals is feared to accelerate the rate of animal extinction if there is no field observation related to the use of animals by the Kanayant Dayak tribe in Temahar village. Related data and animal species, animal parts and circumchations are preliminary indicators to determine the benefits and functions of the animal itself. The method used in this research is the survey method of selecting respondents using the Snowball sampling method, data collection using questionnaire assistance. The results showed the use of animals as much as 16 types. For the ritual of Adat 3 types, treatment 8 types and mystical 5 types. The main parts are meat, bile, fur, heart, blood, kidney, pedals, scales, eggs, liver, and head. Kanayant Dayak people cultivate animal meat for traditional ritual, treatment and mystical by means of cooking gravy and burnt, most people still use traditional equipment to cook and burn meat and for hunting.
\end{abstract}

Keywords: Ethnozoology, Kanayant Dayak, Medicine, Mysticism, Traditional Rituals.

\section{PENDAHULUAN}

Masyarakat pedalaman Kalimantan atau yang dikenal dengan masyarakat Dayak mempunyai ketergantungan dengan alam sekitar yang sangat tinggi. Masyarakat Dayak memanfaatkan tumbuhan dan hewan umtuk memenuhi kebutuhan hidupnya. Pemanfaatan tumbuhan oleh masyarakat Dayak sudah banyak dikaji, namun informasi tentang pemanfaatan hewan oleh masyarakat Dayak belum banyak di ketahui. Hubungan manusia dalam memanfaatkan satwa disebut juga etnozoologi.

Orang Rimba Bukit Duabelas Kabupaten Sarolagun, memanfaatkan 65 jenis hewan liar untuk dikonsumsi (Masyithah, 2016). Masyarakat Dayak
Seberuang di Kecamatan Tempunak Kabupaten Sintang, memanfaatkan 37 jenis satwa untuk dikonsumsi, pengobatan, ritual dan kesenian (Dewin, 2017). Masyarakat Dayak Belangin memanfaatkan 10 jenis spesies satwa untuk obat-obatan (Heningsih, 2018).

Salah satu etnis asli yang terdapat pada Provinsi Kalimantan Barat yaitu suku Dayak Kanayant di Desa Temahar Kecamatan Jelimpo Kabupaten Landak. Masyarakat Dayak Kanayant ini juga memiliki keragaman dalam pemanfaatan fauna baik untuk dikonsumsi obat-obatan, upacara adat dan supranatural. Suku Dayak Kanayant merupakan suku yang masih menjaga budaya leluhur secara turun menurun. Salah satu budaya mereka 
yaitu masih memanfaatkan hewan untuk kebutuhan konsumsi, kebutuhan adat istiadat, kebutuhan pengobatan dan juga bisa dimanfaatkan sebagai simbol kesenian.

Praktek pemanfaatan satwa telah dilakukan oleh sebagian besar suku Dayak Kanayant di Kalimantan Barat untuk kebutuhan hidup sehari-hari, berburu adalah salah satu cara masyarakat Dayak dalam memperoleh hewan buruan. Berburu merupakan salah satu kegiatan penting dalam pemenuhan kebutuhan hidup mereka serta suatu bentuk dari penyesuaian diri manusia terhadap sumberdaya alam bagi masyarakat sekitar hutan yang menggantungkan hidupnya terhadap hutan. Suku Dayak selain memanfaatkan hewan buruan juga berternak untuk kebutuhan hidup seperti berternak babi, ayam, kambing dan lainlain. Kebanyakan Suku Dayak Kanayant berternak babi karena dalam kepercayaan Suku Dayak Kanayant babi merupakan simbolis dalam beberapa upacara ritual adat dan hampir semua ritual adat Dayak Kanayant menggunakan babi dan ayam. Pengetahuan lokal suku Dayak Kanayant mengenai pemanfaatan hewan yang masih bertambah hingga saat ini. Oleh sebab itu perlu adanya penelitian mengenai pemanfaatan satwa oleh masyarakat Dayak Kanayant Di Desa Temahar Kecamatan Jelimpo Kabupaten Landak untuk menghimpun informasi pemanfaatan satwa di daerah tersebut. Tujuan penelitian ini untuk mendapatkan data mengenai jenis satwa yang dimanfaatkan untuk ritual adat, mistis dan pengobatan dan untuk memperoleh data mengenai cara pemanfaatan satwa untuk ritual adat, mistis dan pengobatan oleh suku Dayak Kanayant di Desa Temahar Kecamatan Jelimpo Kabupaten Landak.

\section{METODE PENELITIAN}

Penelitian ini dilaksanakan di Desa Temahar selama \pm 4 minggu setara tanggal 3 Juni sampai dengan tanggal 2 Juli 2019. Penelitian dilakukan menggunakan metode survey dengan wawancara berbantuan kuisioner. Fokus penelitian ini peneliti melakukan di lingkungan pemukiman masyarakat.

Objek penelitian adalah masyarakat Dayak Kanayant di Desa Temahar Kecamatan Jelimpo Kabupaten Landak dan hewan yang dimanfaatkan oleh masyarakat tersebut.

Jenis data yang di ambil adalah data primer dan data sekunder. Data primer diperoleh dari hasil wawancara dengan masyarakat di Desa Temahar Kecamatan Jelimpo Kabupaten Landak, data sekunder merupakan data pelengkap yang diperoleh dari referensi yang meliputi keadaan umum lokasi, keadaan social budaya, aksibilitas dan lain-lain.

\section{HASIL DAN PEMBAHASAN}

Secara administrasi Desa Temahar merupakan wilayah yang berada di Kecamatan Jelimpo Kabupaten Landak. jarak $\pm 7 \mathrm{~km}$ dari Temahar ke Bansal \pm 2 km. Dari simpang Serimbu ke Temahar \pm $28 \mathrm{~km}$. Jarak waktu tempuh dari Ngabang ke Temahar $\pm 2 \mathrm{~km}$ dengan kecepatan 50$60 \mathrm{~km} / \mathrm{jam}$. Mata pencarian masyarakat di Desa Temahar sebagian besar dari sektor pertanian dan perkebunan yang berpola sederhana atau tradisional. 
Masyarakat suku Dayak Kanayant tidak lepas dari adat istiadat yang turun temurun dari nenek moyang dan masih dipertahankan sampai saat ini. Cara hidup masyarakat yang sederhana menjadikan masyarakat masih bergantung hidup pada alam sekitar. Guna memenuhi kebutuhan protein masyarakat Kanayant di Desa Temahar beternak hewan seperti babi, anjing, ayam, itik, dan ikan, tidak jarang masyarakat ke hutan untuk berburu dalam mencari makanan sehari-hari. Suku Dayak
Kanayant masih melakukan beberapa ritual sebagai kebutuhan dalam rangka pengobatan terhadap orang sakit sebagian besar masyarakat masih mempercayai pengobatan secara tradisional dengan mengandalkan tabib dan dukun untuk berobat. Ritual adat yang mereka lakukan untuk pengobatan tergantung dari parah tidaknya penyakit yang diderita. Ritual adat yang masayarakat lakukan untuk pengobatan salah satunya adalah balinggang.

Tabel 1. Jenis-Jenis Hewan Yang Dimanfaatkan Oleh Masyarakat Dayak Kanayant di Desa Temahar untuk Ritual Adat, Mistis dan Pengobatan (Ritual Animals Species That Used by Dayak Kanayant Community in Temahar Village for Ritual, Mystical and Medical).

\begin{tabular}{|c|c|c|c|c|c|c|c|}
\hline No & Nama lokal & Nama umum & Famili & $\begin{array}{c}\text { Jenis } \\
\text { Pemanfaatan }\end{array}$ & $\begin{array}{l}\text { Bagian yang } \\
\text { dimanfaatkan }\end{array}$ & $\begin{array}{c}\text { Teknik } \\
\text { pengambilan }\end{array}$ & $\begin{array}{c}\text { Status di } \\
\text { alam (L/D) }\end{array}$ \\
\hline \multicolumn{8}{|c|}{ Mamalia } \\
\hline 1. & Kasu & Anjing & Canidae & $\begin{array}{l}\text { Ritual } \\
\text { Mistis }\end{array}$ & $\begin{array}{c}\text { Daging,Hati } \\
\text { Darah,Jantung } \\
\text { Ginjal }\end{array}$ & Ditangkap & $\mathrm{L}$ \\
\hline 2. & Owe & Babi & Suidae & Ritual & $\begin{array}{c}\text { Daging,Hati } \\
\text { Jantung,Darah } \\
\text { Ginjal }\end{array}$ & Ditangkap & $\mathrm{L}$ \\
\hline 3. & Pelanuk & Pelanduk & Tragulidae & Pengobatan & $\begin{array}{l}\text { Daging,Kepala } \\
\text { Jantung }\end{array}$ & $\begin{array}{c}\text { Diburu } \\
\text { Ditembak }\end{array}$ & $\mathrm{L}$ \\
\hline 4. & Lanak & Landak & Hystricidae & Pengobatan & $\begin{array}{l}\text { Daging,Bulu } \\
\text { Runcing }\end{array}$ & $\begin{array}{c}\text { Diburu } \\
\text { Ditembak }\end{array}$ & $\mathrm{L}$ \\
\hline 5. & Kalawar & Kelelawar & Ptropdidae & Pengobatan & Daging & Ditembak & $\mathrm{L}$ \\
\hline 6. & Munsangk & Musang & Viverridae & Pengobatan & Daging & Ditembak & $\mathrm{L}$ \\
\hline 7. & Kambing & Kambing & Bovidae & Pengobatan & $\begin{array}{l}\text { Daging } \\
\text { Tanduk }\end{array}$ & Ditangkap & $\mathrm{D}$ \\
\hline $\begin{array}{l}8 . \\
9 .\end{array}$ & $\begin{array}{l}\text { Legoh } \\
\text { Tangiling }\end{array}$ & $\begin{array}{l}\text { Beruang } \\
\text { Trenggiling }\end{array}$ & $\begin{array}{l}\text { Ursidae } \\
\text { Manidae }\end{array}$ & $\begin{array}{l}\text { Pengobatan } \\
\text { Mistis }\end{array}$ & $\begin{array}{l}\text { Empedu } \\
\text { Sisik }\end{array}$ & $\begin{array}{l}\text { Ditembak } \\
\text { Diburu } \\
\text { Ditembak }\end{array}$ & $\begin{array}{l}\mathrm{L} \\
\mathrm{L}\end{array}$ \\
\hline 10. & Kara & Monyet & Hominoidae & Kosumsi & Daging & Ditembak & $\mathrm{L}$ \\
\hline \multicolumn{8}{|l|}{ Aves } \\
\hline 11. & Siap & Ayam & Phasianidae & $\begin{array}{l}\text { Pengobatan } \\
\text { Ritual }\end{array}$ & $\begin{array}{l}\text { Daging,Hati } \\
\text { Drarah,Pedal }\end{array}$ & Ditangkap & $\mathrm{D}$ \\
\hline 12. & $\begin{array}{l}\text { Manuk } \\
\text { Keto }\end{array}$ & $\begin{array}{l}\text { Burung } \\
\text { Keto }\end{array}$ & Dicaeidae & Mistis & - & - & $\mathrm{L}$ \\
\hline 13. & $\begin{array}{c}\text { Manuk } \\
\text { Ceruit }\end{array}$ & $\begin{array}{c}\text { Burung } \\
\text { Ceruit }\end{array}$ & Zosteropidae & Mistis & - & - & $\mathrm{L}$ \\
\hline 14. & $\begin{array}{c}\text { Manuk } \\
\text { Buak }\end{array}$ & Burung Hantu & Strigidae & Mistis & - & $\begin{array}{c}\text { Diburu } \\
\text { Ditembak }\end{array}$ & $\mathrm{L}$ \\
\hline \multicolumn{8}{|c|}{ Reptil } \\
\hline 15. & Cacak & Cicak & Gekkonidae & $\begin{array}{c}\text { Pengobatan } \\
\text { Mistis } \\
\end{array}$ & - & - & $\mathrm{L}$ \\
\hline \multicolumn{8}{|c|}{ Animalia } \\
\hline 16. & Ikan Gabus & Ikan Gabus & $\begin{array}{c}\text { Channa } \\
\text { striata }\end{array}$ & Pengobatan & Dagingnya & Dipancing & $\mathrm{L}$ \\
\hline
\end{tabular}


Sumber: Data Wawancara Bersama Responden Terpilih Desa Temahar 2019, Kecamatan Jelimpo Kabupaten Landak. Keterangan: L (Liar), D (Domestika)

Berdasarkan hasil wawancara oleh masyarakat Dayak Kanayant di diperoleh 15 jenis satwa yang dijadikan Desa Temahar.

untuk Ritual, Mistis, dan Pengobatan

\section{Pemanfaatan Satwa Untuk Ritual Adat}

Tabel 2. Pemanfaatan Hewan Untuk Ritual Adat Oleh Masyarakat Dayak Kanayant, di Desa Temahar (Utilization of Animals for Rituals Tradition by Dayak Kanayant Community, in Temahar Village).

\begin{tabular}{ccccccc}
\hline No & $\begin{array}{c}\text { Nama } \\
\text { lokal }\end{array}$ & $\begin{array}{c}\text { Nama } \\
\text { umum }\end{array}$ & Nama Ilmiah & Ritual Adat & $\begin{array}{c}\text { Bagian yang } \\
\text { dimanfaatkan }\end{array}$ & Makna \\
\hline 1. & Kasu & Anjing & Canis Lupus & $\checkmark$ & $\begin{array}{c}\text { Kepala, Darah } \\
\text { dan Gigi } \\
\text { Seluruh Badan }\end{array}$ & $\begin{array}{c}\text { Mengusir makhluk } \\
\text { halus }\end{array}$ \\
2. & Owe & Babi & Sus Barbatus & $\checkmark$ & $\begin{array}{c}\text { Penangal roh jahat, } \\
\text { memberi sesajian } \\
\text { pada makhluk halus }\end{array}$ \\
3. Siap & Ayam & $\begin{array}{c}\text { Gallus gallus } \\
\text { Domestica sp }\end{array}$ & $\checkmark$ & Hati, Telur & $\begin{array}{c}\text { Memberi sesajian } \\
\text { pada makhluk halus }\end{array}$
\end{tabular}

Sumber: Data Hasil Wawancara Bersama Responden Terpilih di Desa Temahar 2019, Kecamatan Jelimpo Kabupaten Landak

Masyarakat Suku Dayak Kanayant di Desa Temahar masih mempunyai kepercayaan terhadap bebrapa satwa yang digunakan untuk upacara ritual adat. Ritual adat pada suku Dayak Kanayant merupakan tradisi turun temurun dari nenek moyang. Adat istiadat yang masih melekat kental pada masyarakat terutama pada kaum orang tua, dan mereka mengatakan adat istiadat merupakan salah satu cara untuk menghormati tradisi lama dari nenek moyang. Ritual adat pada suku Dayak Kanayant di Desa Temahar mulai dari acara pernikahan, hukum adat, gawai padi, dan ritual lainnya selalu menggunakan hewan untuk dijadikan korban terutama ayam, anjing dan babi.
Pada hukum adat masyarakat Dayak Kanayant mempunyai tingkatan dalam menggunakan hewan terutama anjing dan babi sesuai kesalahan dan norma yang dilanggar.

Menurut kepercayaan masyarakat Dayak Kanayant anjing digunakan dalam upacara adat untuk mengusir roh jahat, serta memberi sesaji kepada makhluk halus. Darah anjing yang dipercikan saat upacara diyakini memberi pembatas pada tempat tinggal antara manusia dan roh jahat, sedangkan kepala anjing yang sudah dipotong dipajang dijalan karena menurut masyarakat roh halus takut akan gigi anjing yang akan menggigit mereka. 


\section{Pemanfaatan Satwa Yang Dianggap Mistis}

Tabel 3. Manfaatan Hewan Yang Dianggap Mistis Oleh Masyarakat Dayak Kanayant, di Desa Temahar (Utilization of Animals Considered Mystical by Dayak Kanayant Community, in Temahar Village).

\begin{tabular}{|c|c|c|c|c|c|}
\hline No & Nama lokal & Nama Umum & Nama Ilmiah & $\begin{array}{c}\text { Bagian yang } \\
\text { dimanfaatkan }\end{array}$ & Makna \\
\hline 1 & Cacak & Cicak & $\begin{array}{c}\text { Hemidactylus } \\
\text { platyurus }\end{array}$ & Kotoran & $\begin{array}{l}\text { Mengusir roh } \\
\text { jahat pada } \\
\text { tubuh }\end{array}$ \\
\hline 2 & Siap & Ayam & $\begin{array}{l}\text { Gallus gallus } \\
\text { domestica sp }\end{array}$ & Suara & $\begin{array}{c}\text { Memberi } \\
\text { pertanda } \\
\text { penampakan } \\
\text { makhluk halus }\end{array}$ \\
\hline 3 & Keto & Burung Keto & $\begin{array}{c}\text { Dicaeum } \\
\text { trigonostigma }\end{array}$ & Suara & $\begin{array}{l}\text { Pertanda } \\
\text { dalam } \\
\text { perjalanan }\end{array}$ \\
\hline 4 & Manuk Buak & Burung Hantu & Otus magicus & Suara & Pertanda buruk \\
\hline 5 & Tangilingk & Trenggiling & Manis javanica & Suara & $\begin{array}{c}\text { Simbol } \\
\text { jelmaan } \\
\text { makhluk halus } \\
\text { dan pertanda } \\
\text { buruk }\end{array}$ \\
\hline
\end{tabular}

Sumber: Data Hasil Wawancara Bersama Responden Terpilih di Desa Temahar 2019, Kecamatan Jelimpo Kabupaten Landak

Ayam sering dihubungkanhubungkan dengan mistis ayam berkokok sebelum subuh menandakan adanya makhluk halus disekitarnya. Cicak dimanfaatkan sebagai hewan mistis menurut masyarakat yang dapat mengusir setan dalam tubuh manusia apabila dengan tidak sengaja cicak membuang kotoran pada manusia tersebut. Burung cabe atau keto merupakan pertanda pada saat keluar rumah, menurut kepercayaan masyarakat Dayak Kanayant apabila burung cabe tersebut bersuara saat hendak keluar rumah diharuskan masuk kembali kedalam rumah sampai burung tersebut tidak lagi bersuara. Karena apabila dilanggar menurut kepercayaan masyarakat kita akan mengalami musibah buruk dalam perjalanan.

Burung hantu atau manuk buak merupakan hewan aktif di malam hari dengan kemampuan unik yang dimilikinya membantu burung hantu memutar kepala mereka hingga 270 derajat. Mistis mengenai burung hantu, masyarakat beranggapan bahwa burung hantu merupakan jelmaan dari makhluk halus sehingga banyak ditakuti sebagai 
masyarakat, yaitu memberi pertanda

buruk.

\section{Pemanfaatan Satwa Untuk Pengobatan}

Tabel 4. Pemanfaatan Hewan Untuk Obat Oleh Masyarakat Dayak Kanayant, di Desa Temahar (Utilization of Animals for Medicine by Dayak Kanayant Community, in Temahar Village).

\begin{tabular}{|c|c|c|c|c|c|c|c|}
\hline No & $\begin{array}{c}\text { Nama } \\
\text { lokal }\end{array}$ & $\begin{array}{l}\text { Nama } \\
\text { Umum }\end{array}$ & Nama Ilmiah & $\begin{array}{c}\text { Bagian yang } \\
\text { dimanfaatkan }\end{array}$ & $\begin{array}{c}\text { Jenis } \\
\text { Penyakit }\end{array}$ & $\begin{array}{c}\text { Cara } \\
\text { Pengolahan }\end{array}$ & $\begin{array}{c}\text { Cara } \\
\text { Pemakaian }\end{array}$ \\
\hline 1. & Lanak & Landak & $\begin{array}{c}\text { Bornean } \\
\text { Porcupine }\end{array}$ & Kotoran & $\begin{array}{c}\text { Keracunan } \\
\text { makanan }\end{array}$ & $\begin{array}{c}\text { Dikeringkan } \\
\text { dicampur } \\
\text { dalam } \\
\text { minuman }\end{array}$ & Diminum \\
\hline 2. & $\begin{array}{l}\text { Dipa } \\
\text { Sawa }\end{array}$ & Ular Sawa & Pythonidae & Ususnya & Koreng & Diawetkan & Dioleskan \\
\hline 3. & $\begin{array}{l}\text { Ikant } \\
\text { Gabus }\end{array}$ & Ikan Gabus & Channa striata & Dagingnya & Luka Daging & Dimasak & Dimakan \\
\hline 4. & Legoh & Beruang & Ursidae & Empedunya & Luka Dalam & Dijemur & Dimakan \\
\hline 5. & Balut & Belut & Synbranchidae & Seluruh Badan & Anemia & Ditumis & Dimakan \\
\hline
\end{tabular}

Sumber: Data Hasil Wawancara Bersama Responden Terpilih di Desa Temahar 2019, Kecamatan Jelimpo Kabupaten Landak

Pemanfaatan satwa sebagai obat tidak hanya bagian lemak satwa tetapi kotoran, kulit, daging, madu, dan seluruh tubuh satwa. Kotoran landak yang dimanfaatkan oleh masyarakat untuk mengobati keracunan makanan, mabuk minuman keras, dan pegal pegal pada tubuh. Cara pengolahannya terlebih dahulu kotoran landak dijemur sampai kering dan dicampurkan sedikit kedalam minuman apabila saat keracunan makanan, mabuk minuman keras dan pegal-pegal.

Penggunaan sebagai obat seperti ular sawa yang dimanfaatkan adalah lemaknya untuk mengobati penyakit koreng dengan cara diawetkan ke dalam botol sampai menjadi minyak kemudian dioleskan. Masyarakat memanfaatkan ular sawa untuk menyembuhkan penyakit korengan.

Selain itu masyarakat juga memanfaatkan beruang sebagai obat yaitu dengan mengambil empedunya kemudian empedu beruang di manfaatkan dengan cara dijemur atau diselai sampai menjadi kering kemudian siap untuk diminum.

\section{Bagian Satwa Yang Dimanfaatkan}

Pemanfaatan bagian satwa oleh masyarakat Dayak Kanayant mulai dari seluruh tubuh sampai pada organ-organ tubuh lainnya. Dapat dilihat pada gambar 2. Pemanfaatan bagian-bagian satwa yang digunakan telah dijelaskan pada tabel 4 . 


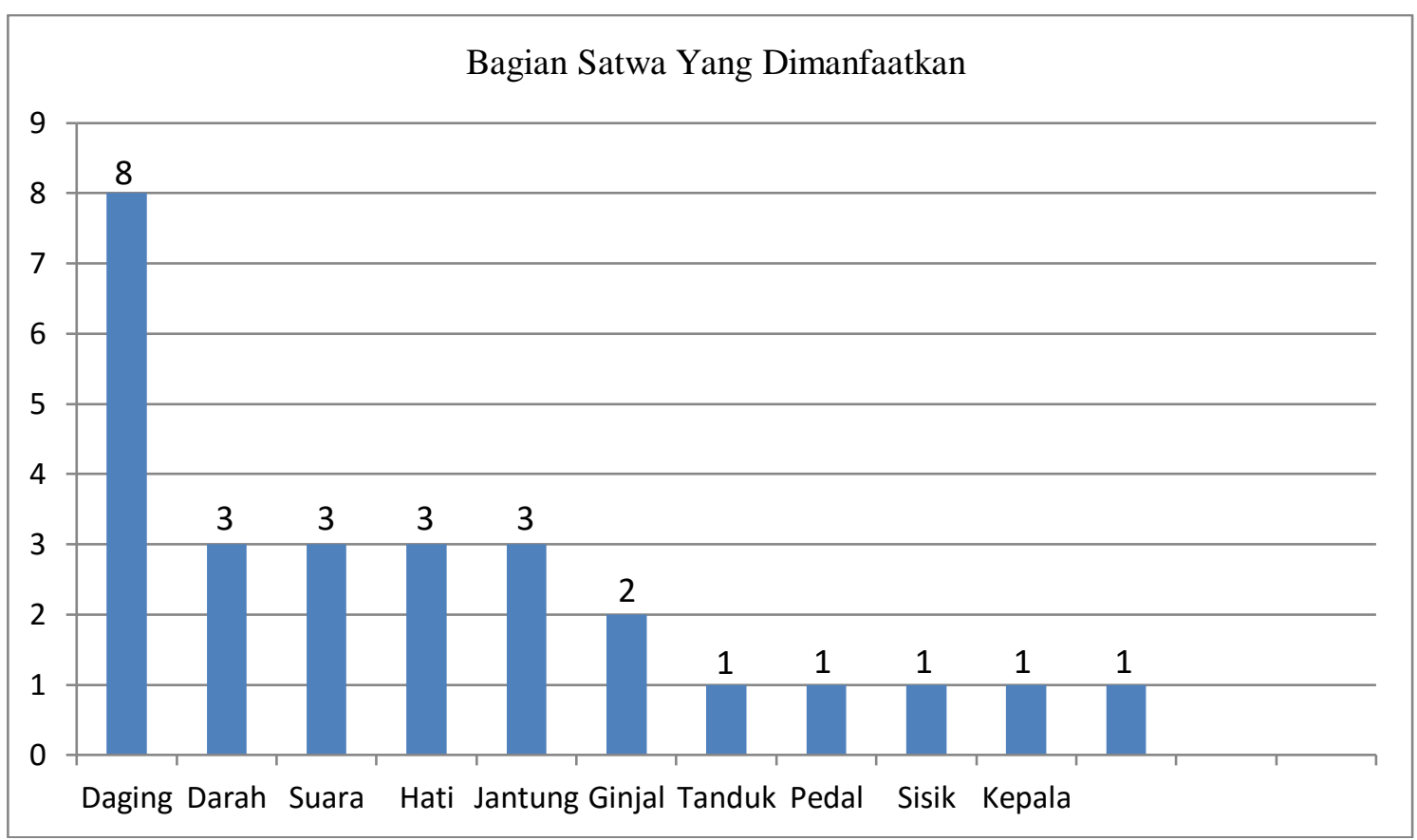

Gambar 1. Diagram Bagian Satwa Yang Dimanfaatkan (Diagram of animal parts that are utilized)

\section{Status Konservasi}

Status konservasi satwa yang dimanfaatkan menurut IUCN dan CITES Appendices dapat dilihat pada tabel 11. IUCN atau (International Union For Conservation Of Nature and Natural Resources) adalah sebuah organisasi internasional yang didedikasikan untuk konservasi sumber daya alam. IUCN akan memperbaiki dan mengevaluasi status setiap species lima tahun sekali jika memungkinkan, atau setidaknya sepuluh tahun sekali. The Convention On International Endangered Species of Wild Fauna And Flora (CITES) konvensi perdagangan internasional untuk spesies-spesies flora dan satwa liar adalah suatu fakta perjanjian internasional yang berlaku sejak tahun 1975. Fokus utama CITES adalah memberikan perlindungan pada spesies tumbuhan dan satwa liar terhadap perdagangan internasional yang tidak sesuai dengan ketentuan yang berlaku, yang mungkin akan membahayakan kelestarian tumbuhan dan satwa liar tersebut.

Sejak 1978 Indonesia telah menjadi parties CITES dan meratifikasi konvensi tersebut dengan keputusan pemerintah no. 43 Tahun 1978. Yang berdasarkan peraturan pemerintah no. 8 Tahun 1999 diwakili oleh kementrian kehutanan sebagai otoritas pengelola CITES di Indonesia dan Lembaga Ilmu Pengetahuan Indonesia (LIPI) sebagai otoritas keilmuan CITES. 
Tabel 5. Status konservasi hewan yang dimanfaatkan oleh suku Dayak Kanayant di Desa Temahar Kecamatan Jelimpo Kabupaten Landak (The conservation status of animals utilized by Kanayant Dayak tribes in Temahar Village, Jelimpo District, Landak Regency).

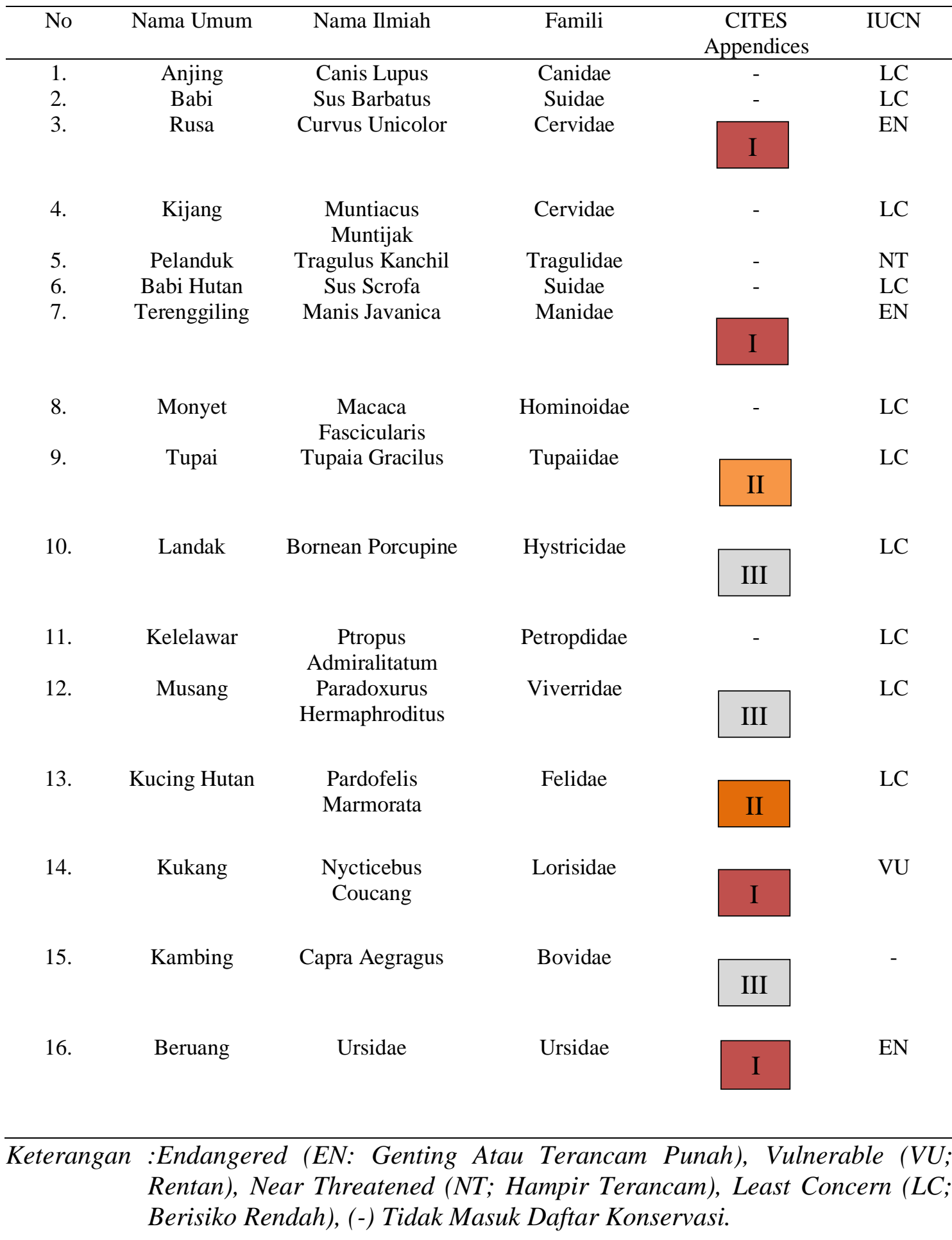




\section{Kesimpulan}

Berdasarkan hasil penelitian tentang hewan dan pemanfaatannya oleh suku Dayak Kanayant di Desa Temahar Kecamatan Jelimpo Kabupaten Landak dapat disimpulkan sebagai berikut:

1. jumlah jenis satwa yang dimanfaatkan oleh masyarakat di Desa Temahar sebanyak 16 jenis satwa yang dimanfaatkan untuk Ritual Adat, Mistis dan Pengobatan.

2. Pemanfaatan satwa oleh masyarakat Dayak Kanayant di Desa Temahar untuk ritual adat sebanyak 3 Jenis, Mistis sebanyak 5 jenis, dan pengobatan sebanyak 8 jenis.

3. Bagian satwa yang dimanfaatkan oleh masyarakat Dayak Kanayant di Desa Temahar mulai dari seluruh badan seperti daging, suara, tulang, darah, tanduk, lemak, kepala, hati, dan kotoran. Daging adalah bagian satwa yang paling banyak digunakan oleh masyarat Dayak Kanayant di Desa Temahar.

4. Cara pemanfaatan satwa yang bervariasi oleh masyarakat Dayak Kanayant di Desa Temahar mulai dari ritual adat, mistis dan pengobatan. Cara pengolahan antara lain: dimasak, ditumis, digoreng, dan dibakar dan cara pemanfaatan antara lain: diminum, dimakan dan dioleskan.

\section{DAFTAR PUSTAKA}

Dwi S, F Rohman, dan Hedi S. 2015. Kajian Etnozoologi Masyarakat Desa Hadiwaarno Kabupaten Pacitan dalam Konservasi Penyu
Sebagai Bahan Penyusunan Booklet Penyuluhan Masyarakat. Jurnal Pendidikan Biologi Indonesia 1 (3) : 283 - 297.

Heningsih, Anwari MS dan Yani A. 2018. Kajian Etnozoologi Untuk Obat-obatan Masyarakat Dayak Belangin di Desa Mu'un Kecamatan Ngabang Kabupaten Landak. Fakultas Kehutanan Universitas Tanjungpura. Jurnal Hutan Lestari. Vol.6 (3) : 647653.

Masyithah. 2016. Kajian Etnozoologi Hewan yang Dikonsumsi pada Komunitas Orang Rimba di Taman Nasional Bukit Duabelas Kabupaten Sorolangun. Fakultas Keguruan Ilmu Pendidikan Universitas Jambi. Jurnal Biosite. Vol. 02 No. 2 : 1-50. 